Article

\title{
Alien Plants in the Eastern Cape Province in South Africa: Perceptions of Their Contributions to Livelihoods of Local Communities
}

\author{
Zizipho Atyosi, Luambo Jeffrey Ramarumo and Alfred Maroyi *(D) \\ Medicinal Plants and Economic Development (MPED) Research Centre, Department of Botany, University of \\ Fort Hare, Private Bag X1314, Alice 5700, South Africa; atyosizizipho@gmail.com (Z.A.); \\ luambo@safrica.com (L.J.R.) \\ * Correspondence: amaroyi@ufh.ac.za; Tel.: +27-719600326
}

Received: 31 March 2019; Accepted: 14 May 2019; Published: 16 September 2019

check for updates

\begin{abstract}
Invasive alien plant species are plant species that establish themselves outside their native distributional range. The current study documented utilization of alien plant species in the Eastern Cape province in South Africa. Information about utilization of alien plant species was gathered through interviews conducted with 120 participants, which included 13 traditional healers, 27 herbalists, ten farmers and 70 laypeople. Ethnobotanical importance of documented species was assessed through evaluation of use value (UV), fidelity level (FL) and relative frequency citation (RFC). A third of the participants (33.3\%) perceived alien plant species as undesirable, while $71.1 \%$ of the participants argued that alien plant species had beneficial effects. A total of 26 alien plant species were recorded, seven species being fruit trees, followed by ornamental plants (five species), fodder and herbal medicines (four species each), construction materials, erosion control and vegetables (two species each). The popular alien plant species with UV $>0.1$ RFC $>0.4$ and FL $>4.0 \%$ included Amaranthus spinosus, Cannabis sativa, Cereus jamaracu, Harrisia balansae, Opuntia engelmannii, Opuntia ficus-indica, Opuntia monocantha and Prunus persica. Information on perceptions of local communities in the Eastern Cape province on the contributions of alien plant species to livelihood needs is an important stage of initiating a management protocol that incorporates public perceptions and values associated with alien plant species.
\end{abstract}

Keywords: alien plant species; conservation; Eastern Cape province; perceptions and attitudes of laypersons; South Africa

\section{Introduction}

Invasive alien plant species are plant species that establish themselves outside their native distributional range. Pyšek et al. [1] defined invasive alien plants as introduced species that constitute a self-sustaining population, consistently producing offspring in large numbers and at considerable distances from the parent plants with the potential to spread over a large area. The Convention on Biological Diversity (CBD) Conference of Parties defined an invasive alien species as a species outside its native geographical range, whose introduction and spread threatens biodiversity [2]. Over the last few decades, there has been an increase in the spread of alien plant species due mainly to the increasing anthropogenic activities [3,4]. The harmful ecological effects of alien plant species on natural ecosystems, economy and human health are well documented with Shackleton and Shackleton [5] arguing that there is need to evaluate the positive and negative impacts of alien plant species on biodiversity, humankind and economy.

Several alien plant species are known to decrease indigenous plant species diversity, alter the rate of nutrient cycling in ecosystems and increase their productivity in the process, and have a direct 
effect on ecosystem goods and services and the well-being of local communities [6-11]. However, the use of alien plant species in maintaining rural livelihoods has received less attention and is not well understood and usually not factored into invasive alien species control and monitoring programmes [5,12-14]. Research by Shackleton et al. [12] showed that several households in the Eastern Cape province in South Africa traded in alien plant species products to generate supplementary income. Similarly, Kull et al. [15] argued that control of invasive Australian acacias should be carefully managed so as not to adversely impact poor communities that are dependent on the species for their livelihood needs. These authors argued that poorer communities in peri-urban, rural and marginalized areas rely on Australian acacias for household livelihood needs and, sometimes, for income generation, while middle-income areas often have private farm investments focusing on acacia woodlots for commercial purposes.

Understanding the use of alien plant species by rural communities in peri-urban, rural and marginalized areas, and factoring these aspects into cost-benefit models is complex, as this is dependent on a wide range of factors, including abundance, time since invasion, local-level costs and benefits [12]. The impacts of alien plant species can generally be reliably evaluated through an assessment of local knowledge and the social benefits associated with alien plant species, as it is often people that influence plant distribution and the need for managing invasions by alien plant species to minimize the ecological, economic and cultural impacts associated with these species [13,16]. According to Bennett and Prance [17], Srithi et al. [18] and Baral et al. [19], some alien plant species regarded as weeds are utilized by local communities as food and medicines. Baral et al. [19] argued that incorporation of local knowledge into alien plant species management could significantly contribute to the change of public perceptions and values associated with alien plant species. These authors argued that there is a need to understand what the rural dwellers know and what they need to know about alien plant species [19]. Zengeya et al. [20] argued that the main reasons for introducing alien plant species in different localities are to get household sustenance through their utilization, ecosystem services such as erosion control and dune stabilisation. These authors argued that alien plant species with high societal values have been widely disseminated and in some areas they are now conspicuous components of the natural ecosystems. The movement and entry of alien plant species into a locality and ecological, economic and cultural changes associated with movement of these species is due to globalization and international trade [21-24]. Richardson and Rejmanek [25] argued that large quantities of invasive trees and bushes shifted between areas of the world and these rates of spread differ significantly from region to region of the world [26]. Research by Willis et al. [27] revealed that numerous plant species become taller, healthier and have a higher regenerative limit where they are not native. Similarly, Stastny et al. [28] argued that plant species may become invasive due to a lack of natural enemies in their introduced range, which usually leads to a trade-off with vigour or competitive ability. Arguments presented by Richardson and Rejmanek [25], Richardson and Pyšek [26], Willis et al. [27] and Stastny et al. [28] appear to support the observation made by Vilà and Weiner [29] that invasive plants seem to be more competitive than native species. Research by Rai et al. [30] showed that some farming communities are adapting to the positive contributions associated with alien plant species as some of the species serve as pioneer communities and are also used as organic compost.

Research by Heink and Jax [31] showed that discussions about alien plant species management, control and plant species conservation often neglect values that local communities associate with these species. In South Africa, there is overwhelming evidence that alien plant species are often used as food, medicines and other ecosystem services, such as support and regulatory [12,16,20,32-38]. Many invasive plant species have commercial value as forest and fodder trees, some species have amenity, aesthetic, cultural and historical values making control contentious among different sectors of South African society [39]. For example, several invasive plant species such as Acacia dealbata Link, A. mearnsii De Wild. Opuntia ficus-indica (L.) Mill., O. robusta J.C. Wendl. and O. stricta (Haw.) Haw. provide supporting and regulatory services such as building materials, firewood, food, medicines, fodder, green manure, horticultural material and provide local communities with income through selling 
various plant products [14,15,40,41]. According to Bremner and Park [42], management of invasive alien species is both a social and scientific issue. Research by Bertolino and Genovesi [43] revealed that the local community's support and participation is important to the failure or success of prevention, eradication and control measures of alien plant species. Research by Lindemann-Matthies [44] showed that the willingness of laypersons to remove and report the presence of invasive exotic plant species in Switzerland decreased with increasing desirability and thus ornamental value of the species. The author also argued that perceptions and attitudes of laypersons on species conservation may strongly differ from those of natural resource managers and conservationists, as the laypersons may not support the removal or eradication of useful alien species, especially those used as ornamentals. It is within this context that the current research was undertaken, aimed at evaluating perceptions of local communities in the Eastern Cape province in South Africa regarding contributions of alien plant species to the livelihood needs of the local community. The study contributes to research literature on public perceptions of alien plant species and attitudes toward the current management protocols and strategies on different biodiversity components [14,42,44-53]. Results of this study will also provide the baseline data required for evaluating alien plant species diversity, utilization, existing perceptions and attitudes of laypersons in South Africa towards alien plant species. This paper aims to fill the knowledge gap on local peoples' attitudes, perceptions and management strategies required to control and contain potential invasion of alien plant species in the Eastern Cape province in South Africa.

\section{Materials and Methods}

\subsection{Study Area}

This study was conducted in Khayamnandi village in Alice, the Eastern Cape province in South Africa (Figure 1). The climate of the study area can be described as mild with most rain falling during summer months from September to April, with annual rainfall averaging $600 \mathrm{~mm}$ [54]. The climate varies from hot in summer to extreme cold in winter with heavy snowfall, with temperature ranging from $5{ }^{\circ} \mathrm{C}$ in July to $37^{\circ} \mathrm{C}$ in February [54]. The dominant land use practices in the study area are livestock production, small-scale vegetable and dryland crop production. Mucina and Rutherford [55] described the vegetation of the study area as grassland, succulent thicket and Acacia thornveld dominated by Melinis nerviglumis (Franch.) Zizka, Eragrostis curvula (Schrad.) Nees, Vachellia karroo (Hayne) Banfi \& Glasso and Aloe ferox Mill.

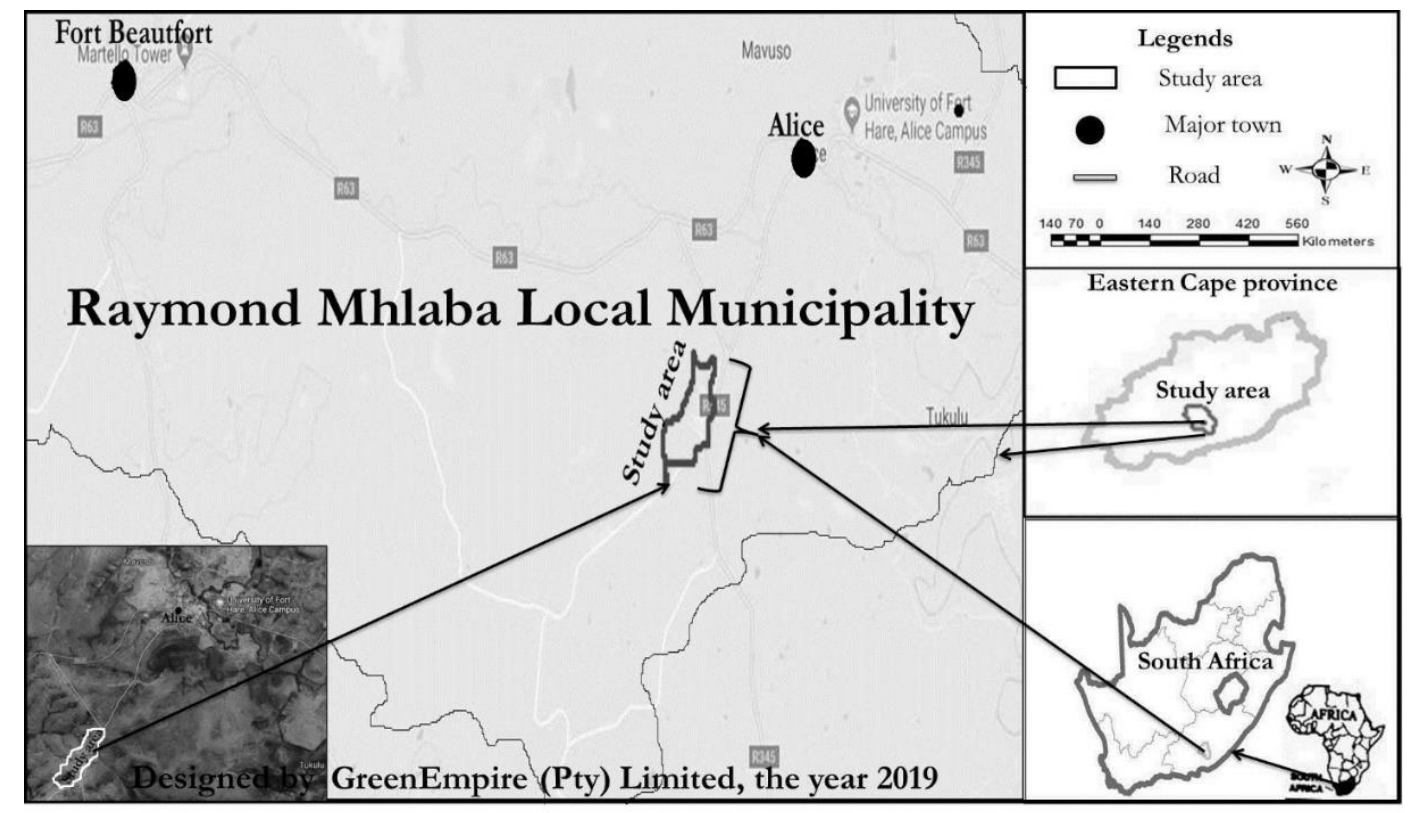

Figure 1. Map showing the location of the study site in relation to other areas in South Africa and Africa. 


\subsection{Data Collection}

Information on alien plant species used in Khayamnandi village, their use categories and the indigenous knowledge associated with them was gathered using semi-structured and open-ended questionnaires. Participatory rural appraisal (PRA) methods were used [56,57] to systematically collect data and information on the following aspects:

1. socio-demographic characteristics of participants;

2. vernacular names of alien plants;

3. uses of alien plants;

4. characteristics of alien plants;

5. ecological impacts of alien plants; and

6. other benefits and additional information on alien plants.

Field trips were made to the sites where the participants harvested alien plants and voucher specimens of plants identified as alien plants were collected during the field trips when encountered for the first time and again when they were flowering or fruiting, for easy identification [58]. The collected voucher specimens were processed using standard taxonomic procedures [59-61]. Each herbarium specimen included important plant parts such as leaves, stems, flowers and fruits whenever available. For small annual, biennial herbaceous and subshrub plants, the whole plants were collected [59-61]. These specimens were deposited for future reference at the Giffen Herbarium, University of Fort Hare, Alice campus, South Africa.

One hundred and twenty participants were randomly selected and interviewed between March and June 2018 (Figure 2). The decision to select one hundred and twenty participants was informed by research carried out by Crouch and McKenzie [62], Guest et al. [63] and Latham [64] that showed that saturation often occurs when 12 participants are selected in homogeneous groups and for a heterogenous sample, the number of participants should be at least 12. Among the selected participants were 70 males (58.3\%), 50 females (41.7), 13 traditional healers (10.3\%), 27 herbalist $(22.5 \%)$, ten farmers $(8.3 \%)$ and 70 laypeople (58.3\%) (Figure 2). The majority of the participants $(48.3 \%)$ were between 36 and 55 years, while $32.5 \%$ were between 18 and 35 years. Close to half of the participants (43.3\%) were educated up to primary level, while illiterate, educated up to secondary and tertiary levels were $18.3 \%$, $20.8 \%$ and $17.5 \%$, respectively. More than half of the participants $(54.2 \%)$ were single, $20.8 \%$ were married, $16.7 \%$ were widowed and $8.3 \%$ were divorced. More than half of the participants $(52.5 \%)$ were unemployed and depended on government grants as sources of income (35.8\%) (Figure 2).

Results generated through the questionnaire were supplemented by personal observations, informal discussions and guided field walks with the participants. The data collected in this study were qualitative in nature, and were therefore, explained directly. Qualitative data generated through the questionnaires were coded and sorted into themes, paying particular attention to inconsistencies and unique statements.

Ethnobotanical data were analysed using the frequency relative citation (RFC), fidelity level (FL) and use value (UV), to determine the level of importance of alien plant species based on participants' perceptions.

According to Shuiab et al. [65], the use value (UV) shows the relative importance value of locally recognized plants, and this parameter is calculated as follows:

$$
\mathrm{UVi}=\sum \mathrm{Ui} / \mathrm{N}
$$

where UV is the use value of individual taxon, and $\mathrm{U}$ is the number of uses documented for that taxon and $\mathrm{N}$ is the number of participants who mentioned the taxon [66]. 


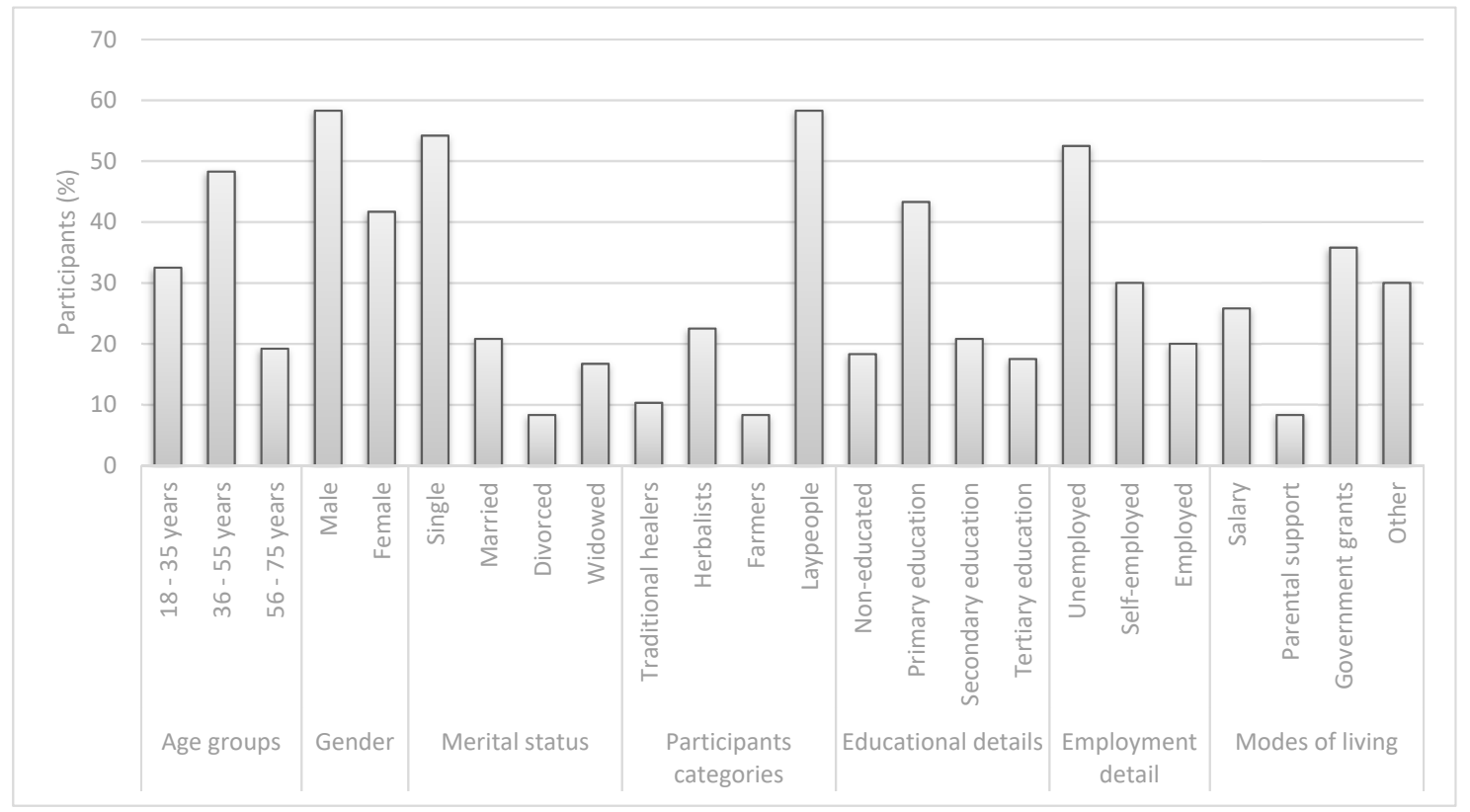

Figure 2. Participants' demographic details.

The frequency relative citation (RFC) was calculated using the following formulae:

$$
\mathrm{RFC}=\mathrm{FC} / \mathrm{N}
$$

where FC is the total number of participants mentioning the use of the taxon divided by the total number of participants taking part in the study $(\mathrm{N})[67,68]$.

Fidelity level (FL) was determined as a means to assess the relative importance of documented alien plant species [68]. Fidelity level (FL) was computed using the following formulae:

$$
\mathrm{FL}=\mathrm{Np} / \mathrm{N} \times 100
$$

where $\mathrm{Np}$ is the total number of participants mentioning the plant taxon for a certain use category and $\mathrm{N}$ is the total number of participants who use the mentioned plant taxon [69].

Box plots featuring medians, first and third quartiles and a range of benefits associated with alien plant species identified in this study, which included ecological, economic, social and therapeutic, were computed using Palaeontological Statistics [70], version 3.24.

\section{Results and Discussion}

\subsection{Perceptions Towards Alien Plants}

A third of the participants (33.3\%) perceived alien plant species as undesirable arguing that they outcompete native species (Table 1). Other participants argued that alien plant species have efficient seed production, dispersal, germination and colonization mechanisms (29.2\%), have rapid growth rates (22.5\%) and are widespread and mainly growing as weeds (15.0\%) (Table 1). Interviews with participants revealed that some of the alien plant species recorded in this study were growing in sites where they were not wanted, and therefore, were considered to be weeds by $15.0 \%$ of the participants (Table 1). Interviews with participants also revealed that more than three quarters of the participants ( $81.7 \%$ ) appreciated work being done by non-governmental organizations, such as Working for Water, through educating local people about alien plant species and relevant policies such as the National Environmental management: Biodiversity Act (NEMBA) and Conservation of Agricultural Act (CARA). About $13.3 \%$ of the participants lacked knowledge of relevant policies governing control 
and management of alien plant species, as well as negative and positive attributes associated with these species. Interviews with participants revealed that Working for Water regularly removes alien plant species in the village and provides the local people with alternative indigenous species that can be cultivated instead of alien plant species. Several alien plant species are categorized as agricultural weeds in South Africa and have been declared invaders and weeds according to the Conservation of Agricultural Resources Act (CARA) No. 43 of 1983 [71,72]. This act prescribes methods of controlling or eradicating any alien plant species listed under CARA, and prohibits growing, selling or transportation of any propagule material of these alien plant species [71,72]. The CARA list is updated regularly and there are three categories of declared weeds and plant invaders and the act prescribes the actions that landowners are expected to take to control CARA listed species. All prohibited weeds that must be controlled in all situations are listed as Category 1. Plants with commercial value that might be planted in demarcated areas provided the landowner has a permit, necessary steps are taken to control spread, and the species is not planted in wetlands and riparian areas are listed in Category 2. Plants characterized by ornamental value that may not be planted or traded are listed in Category 3. In 2004, the South African government enacted the National Environmental Management: Biodiversity Act 2004 (Act No.10 of 2004), NEMBA aimed at developing a more coherent legislative framework to regulate alien plant species [73]. The regulations list 379 alien plant species that must be regulated and controlled, and must not propagated, moved, imported or sold [73]. In 1995, the Republic of South Africa launched the Working for Water programme aimed at removing high water-consuming exotic plants throughout the country with pro-poor rural employment opportunities [74,75]. Through an integrated clearing programme that includes mechanical, chemical and biological control, the Working for Water programme has cleared several hectares previously occupied by alien plant species, provided jobs and training to thousands people from the most marginalized sectors of society, with the majority of them being women [53,75-77]. Legislations such as CARA and NEMBA and the creation of the national framework for invasive exotic plants through the Working for Water Programme significantly increased public awareness about alien plant species in South Africa [75]. According to Van Wilgen and Wannenburgh [39], the South African government has spent around US $\$ 500$ million through the Working for Water Programme to manage exotic invasive species in the country, educating particularly rural communities against the possession, importation, purchase, transportation and introduction of alien plant species.

Table 1. Characteristics of alien plant species based on perceptions of participants.

\begin{tabular}{cccccc}
\hline $\begin{array}{c}\text { Characteristics of Alien } \\
\text { Plant Species }\end{array}$ & Traditional Healers & Herbalists & Farmers & Laypeople & $\%$ \\
\hline Rapid growth rate & 4 & 6 & 7 & 10 & 22.5 \\
\hline $\begin{array}{c}\text { Efficient seed dispersal, germination } \\
\text { and colonization }\end{array}$ & 4 & 4 & 12 & 15 & 29.2 \\
\hline Widespread and growing as weeds & 1 & 2 & 10 & 5 & 15.0 \\
\hline $\begin{array}{c}\text { Undesirable as they outcompete } \\
\text { native species }\end{array}$ & 3 & 5 & 7 & 25 & 33.3 \\
\hline
\end{tabular}

The majority of participants $(71.1 \%)$, which included the traditional healers, herbalists, farmers and laypeople, highlighted the benefits associated with alien plant species in the study area (Figure 3A). These four groups of participants, that is, traditional healers, herbalists, farmers and laypeople, differed in their degree of knowledge, attitudes, perceptions and ecological impacts of alien plant species (Figure 3A,B). Close to three quarters of the participants (71.1\%) argued that alien plant species were beneficial, while a small proportion (10.0\%) argued that alien plant species had detrimental effects (Figure 3A). The benefits associated with alien plant species included pharmaceutical when alien plant species were used as herbal medicines, economical when traded, and participants mentioned ecological and social values associated with some of the species (Figure 3B). Laypeople regarded alien plant species as multipurpose resources characterized by economical, ecological, social and therapeutic 
values, while traditional healers and herbalists recognized mainly therapeutic and to some extent economic and social values of alien plant species (Figure 3B). The therapeutic and economic values of alien plant species were associated with high frequencies (Figure 4) in comparison with ecological and social values. We found high awareness and differentiated knowledge of alien plant species among the participants. The participants attributed utilitarian, cultural, aesthetic, humanistic and ecological values to alien plant species. Our results revealed some level of tolerance and acceptance of alien plant species based on the benefits associated with these plant resources. These findings contradict observations made by Schüttler et al. [50] who found alien plant species to be associated with their negative ecological impacts, with the majority of the local communities in South America recommending different control strategies for alien plant species aimed at reducing their perceived negative impacts and as a means of generating income for poorer households. Similarly, research by Genovesi [47] revealed that differences in perceptions of costs and benefits, knowledge and value systems of alien plant species and lack of confidence in natural resource managers and conservationists have been identified as the main reasons for such public opposition to the removal of alien plant species. The fact that different groups of participants demonstrated different perceptions about impacts and benefits of alien plant species and different attitudes toward their eradication, introduction or management protocols, it implies that any decision-making process regarding control of alien plant species should take into consideration local peoples' perceptions.
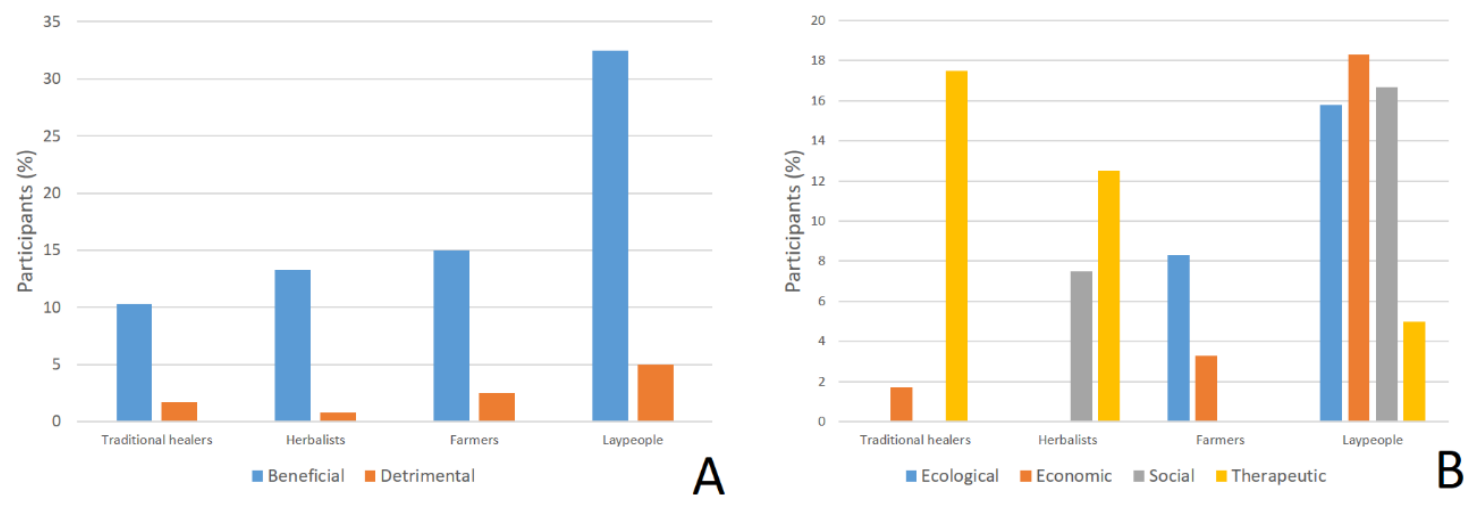

Figure 3. Perceptions of participants about beneficial or detrimental effects of exotic plant species to the local community (A) and some benefits associated with alien plant species in the study area (B).

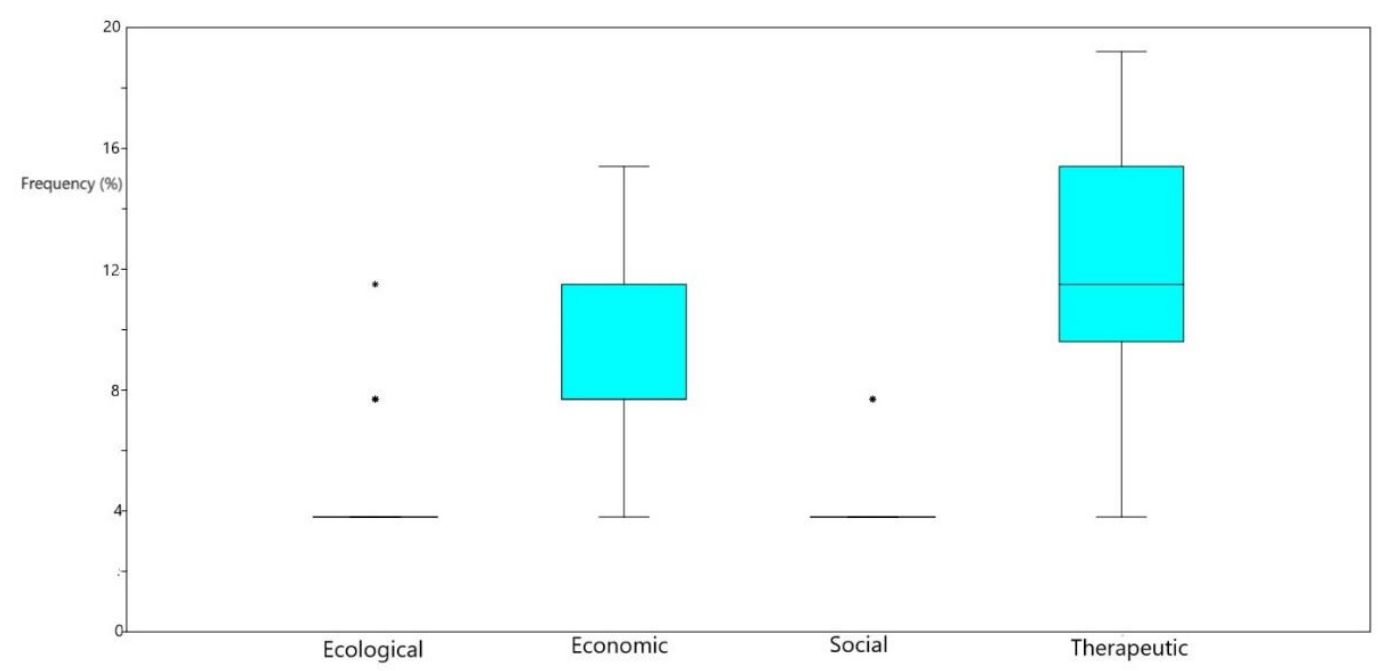

Figure 4. Percentage of species contributing to each of the beneficial values of alien plant species in the study area. 


\subsection{Utilization of Alien Plants}

A total of 26 alien plant species were recorded (Table 2) with $61.5 \%$ of the recorded species belonging to five families (Table 3), the other ten families were represented by one species each. Major plant families with the highest number of species were Cactaceae (five species), Poaceae (four species), Asteraceae (three species), Myrtaceae and Pontederiaceae (two species each) (Table 3). The majority of alien plant species recorded in this study (seven species) were fruit trees, followed by ornamental plants (five species), fodder and herbal medicines (four species each), construction materials, erosion control and vegetables (two species each) (Figure 5). Other minor uses of alien plant species included use of Agave americana L. as a source of fibre, smoking of Cannabis sativa L. for recreational purposes and Pinus halepensis Mill. used as a source of firewood (Table 3). All alien plant species recorded in this study with the exception of Nothoscordum borbonicum Kunth. have local isiXhosa names (Table 3), implying that these plant species are useful to the local community as local people rarely name plant species that they do not use [78]. The popular alien plant species with UV $>0.1, R F C>0.4$ and FL $>4.0 \%$ included the following: Amaranthus spinosus L., Cannabis sativa L., Cereus jamaracu DC., Harrisia balansae (K.Schum.) N.P.Taylor \& Zappi, Opuntia ficus-indica (L.) Mill., Opuntia engelmannii Salm-Dyck ex Engelm., Opuntia monocantha Haw. and Prunus persica (L.) Batsch (Table 3). The fidelity level (FL) value used to assess the degree of importance of alien plants in the Eastern Cape province shows the ratio between the number of informants who independently suggested the use of alien species for the same major purpose and the total number of informants who mentioned the plant for any other use $[68,69]$. The relative frequency of citation (RFC) is the summation of the use report of alien plants based on all interviewed participants for a particular species without considering the use categories $[67,68]$. The use-value (UV) index of alien plants was used to calculate the citation of plants during interviews and to evaluate the useful of a species in comparison with other alien plants among the same sample [66]. Therefore, these three ethnobotanical indices, that is, FL, RFC and UV, were used to identify the most important and useful alien plants in the study area.

More than half of the species documented in this study (61.5\%) are listed in categories 1 to 3 of CARA or NEMBA (Table 4), requiring compulsory control under South Africa's regulatory policies. Previous research on invasive plants in South Africa by Nel et al. [79] classified Agave americana L., Arundo donax L., Cereus jamaracu, Eichhornia crassipes (Mart.) Solms, Opuntia engelmannii, Opuntia ficus-indica, Opuntia monocantha, Psidium guajava L., and Salix babylonica L. as well-established weeds or invaders and causing substantial environmental damage in the country. Therefore, results of the current study make an enormous contribution towards understanding the positive benefits that are associated with alien plant species at the community level. This information is required by conservation managers, government workers, policy-makers and other scientists when drafting species management protocols required to prevent, control, manage or eradicate alien plant species. Novoa et al. [14] highlighted the need for a consultative process involving local communities and other stakeholders when making decisions about controlling or regulating alien species, especially when the stakeholders who benefit from alien species are different from those who suffer the costs. Our findings corroborate observations made by Pfeiffer and Voeks [13] that alien plant species are characterized by complex ecological, economic and cultural effects. Different benefits such as ecological, economic, social and therapeutic, and also detrimental effects were mentioned and quantified by the participants. Other researchers, for example, Alencar et al. [80,81] are of the opinion that indigenous medical systems are influenced by the availability of exotic species in local communities as indigenous pharmacopoeias not static social institutions, but evolve over time, with evidence of deletions and insertions of plants that compose it, with the addition of alien plants as herbal medicines. Bennett and Prance [17] argued that alien plant species that are used by cultural groups as ornamental plants or sources of food, might be introduced into the indigenous pharmacopoeias of local communities mainly because of the use-versatility of such species. 
Table 2. List of alien plant species recorded in the Eastern Cape province in South Africa.

\begin{tabular}{|c|c|c|c|c|c|c|c|}
\hline Species and Family Name & Growth Form & Vernacular Xhosa Names & Uses & UV & RFC & FL (\%) & CARA/NEMBA Categories \\
\hline Agave americana L., Agavaceae & Shrub & Umbholompo & Fibre & 0.2 & 0.02 & 1.7 & 3 \\
\hline $\begin{array}{l}\text { Amaranthus spinosus L., } \\
\text { Amaranthaceae }\end{array}$ & Herb & Utyuthu & Vegetable & 0.14 & 0.06 & 5.8 & Not listed \\
\hline Arundo donax L., Poaceae & Grass & Intsasela & Construction material & 0.3 & 0.03 & 2.5 & $1 \mathrm{~b}$ \\
\hline Avena fatua L., Poaceae & Grass & Ihabile & Fodder & 0.3 & 0.003 & 3.3 & Not listed \\
\hline $\begin{array}{c}\text { Bambusa glaucescens (Willd.) Munro, } \\
\text { Poaceae }\end{array}$ & Grass & Ingcongolo & Construction material & 0.5 & 0.02 & 1.7 & Not listed \\
\hline Bidens pilosa L., Asteraceae & Herb & Umhlabangula & Vegetable & 0.3 & 0.03 & 2.5 & Not listed \\
\hline Bromus catharticus Vahl, Poaceae & Grass & Irhasi & Fodder & 0.3 & 0.003 & 3.3 & Not listed \\
\hline Cannabis sativa L., Cannabaceae & Shrub & Intsangu & Recreational & 0.2 & 0.04 & 4.2 & Not listed \\
\hline Cereus jamaracu DC., Cactaceae & Shrub & Unoroshe & Fodder & 0.2 & 0.05 & 5.0 & $1 \mathrm{~b}$ \\
\hline $\begin{array}{l}\text { Eichhornia crassipes (Mart.) Solms, } \\
\text { Pontederiaceae }\end{array}$ & Herb & Inyibiba & $\begin{array}{c}\text { Ornamental and erosion } \\
\text { control }\end{array}$ & 0.3 & 0.02 & 1.7 & $1 \mathrm{~b}$ \\
\hline $\begin{array}{l}\text { Harrisia balansae (K. Schum.) N. P. } \\
\text { Taylor and Zappi, Cactaceae }\end{array}$ & Shrub & Ukatyi & Edible fruits & 0.2 & 0.04 & 4.2 & $1 \mathrm{a}$ \\
\hline Morus alba L. var. alba, Moraceae & Tree & Amaqunube & Edible fruits & 0.5 & 0.02 & 1.7 & 3 \\
\hline $\begin{array}{l}\text { Nothoscordum borbonicum Kunth., } \\
\text { Alliaceae }\end{array}$ & Herb & - & Herbal medicine & 0.6 & 0.03 & 2.5 & Not listed \\
\hline $\begin{array}{l}\text { Opuntia engelmannii Salm-Dyck ex } \\
\text { Engelm., Cactaceae }\end{array}$ & Shrub & Unochwane & Fodder & 0.1 & 0.07 & 6.7 & $1 \mathrm{~b}$ \\
\hline $\begin{array}{l}\text { Opuntia ficus-indica (L.) Mill., } \\
\text { Cactaceae }\end{array}$ & Shrub & Undyumbe & Edible fruits & 0.1 & 0.08 & 7.5 & $1 \mathrm{~b}$ \\
\hline Opuntia monocantha Haw., Cactaceae & Shrub & Tolofiya & Edible fruits & 0.1 & 0.08 & 8.3 & $1 \mathrm{~b}$ \\
\hline Phytolacca dioica L., Phytolaccaceae & Tree & Umvumvu & Ornamental & 0.5 & 0.02 & 1.7 & 3 \\
\hline Pinus halepensis Mill., Pinaceae & Tree & Ipayina & $\begin{array}{l}\text { Ornamental and } \\
\text { firewood }\end{array}$ & 0.3 & 0.003 & 3.3 & 2 \\
\hline
\end{tabular}


Table 2. Cont.

\begin{tabular}{|c|c|c|c|c|c|c|c|}
\hline Species and Family Name & Growth Form & Vernacular Xhosa Names & Uses & UV & RFC & FL (\%) & CARA/NEMBA Categories \\
\hline $\begin{array}{l}\text { Pontederia cordata L. var. ovalis Solms, } \\
\text { Pontederiaceae }\end{array}$ & Herb & Ingcongolo & $\begin{array}{c}\text { Ornamental and erosion } \\
\text { control }\end{array}$ & 0.1 & 0.01 & 0.8 & $1 \mathrm{~b}$ \\
\hline Prunus persica (L.) Batsch, Rosaceae & Tree & Umthi wepesika & Edible fruits & 0.2 & 0.05 & 5.0 & Not listed \\
\hline Psidium guajava L., Myrtaceae & Tree & Igwava & Edible fruits & 0.3 & 0.03 & 2.5 & 2 \\
\hline Salix babylonica L., Salicaceae & Tree & Umngcunube & Ornamental & 0.3 & 0.03 & 2.5 & 2 \\
\hline $\begin{array}{c}\text { Syzygium paniculatum Gaertn., } \\
\text { Myrtaceae }\end{array}$ & Tree & Irharinati & Edible fruits & 0.1 & 0.01 & 0.8 & Not listed \\
\hline Tagetes minuta L., Asteraceae & Herb & Buhlungubebhokwe & Herbal medicine & 0.5 & 0.02 & 1.7 & Not listed \\
\hline $\begin{array}{l}\text { Toxicodendron succedaneem }(\mathrm{L} .) \\
\text { Kuntze, Anacardiaceae }\end{array}$ & Tree & Gamtriya & Herbal medicine & 0.3 & 0.003 & 3.3 & $1 \mathrm{~b}$ \\
\hline Xanthium spinosum L., Asteraceae & Herb & Itshungu & Herbal medicine & 1.5 & 0.02 & 1.7 & $1 \mathrm{~b}$ \\
\hline
\end{tabular}


Table 3. Plant families with the largest number of alien plant species (with more than two species).

\begin{tabular}{ccc}
\hline Family & Number of Species & \% \\
\hline Cactaceae & 5 & 19.2 \\
Poaceae & 4 & 15.4 \\
Asteraceae & 3 & 11.5 \\
Myrtaceae & 2 & 7.7 \\
Pontederiaceae & 2 & 7.7 \\
\hline
\end{tabular}

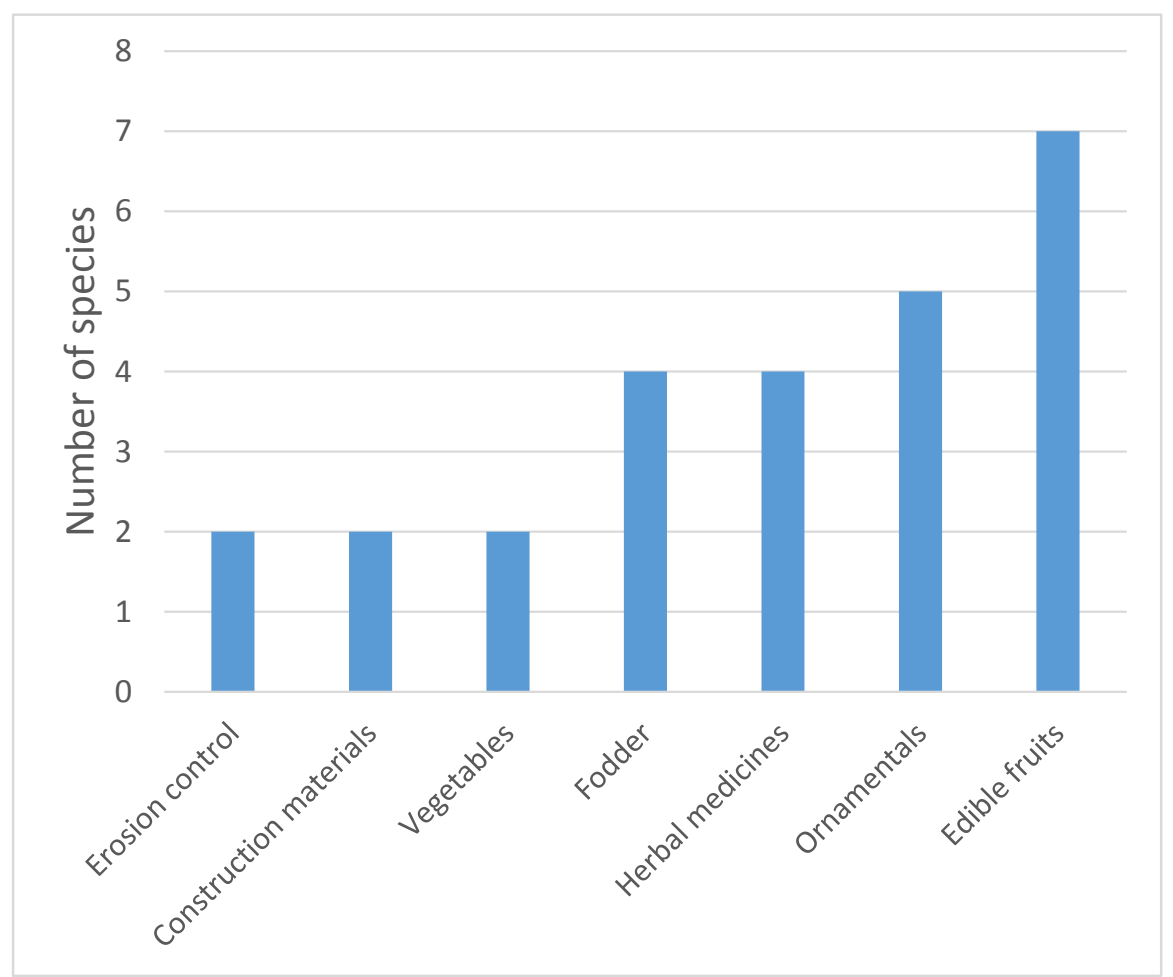

Figure 5. Major use categories of alien plant species in the Eastern Cape province in South Africa.

Table 4. CARA or NEMBA categories of alien plant species recorded in the Eastern Cape province in South Africa.

\begin{tabular}{ccc}
\hline Species Name & CARA/NEMBA Categories & Invasion Status \\
\hline Harrisia balansae & $1 \mathrm{a}$ & Weed \\
Arundo donax & $1 \mathrm{~b}$ & Weed \\
Cereus jamaracu & $1 \mathrm{~b}$ & Weed \\
Eichhornia crassipes & $1 \mathrm{~b}$ & Weed \\
Opuntia engelmannii & $1 \mathrm{~b}$ & Weed \\
Opuntia ficus-indica & $1 \mathrm{~b}$ & Weed \\
Opuntia monocantha & $1 \mathrm{~b}$ & Weed \\
Pontederia cordata var. ovalis & $1 \mathrm{~b}$ & Weed \\
Toxicodendron succedaneem & $1 \mathrm{~b}$ & Weed \\
Xanthium spinosum & $1 \mathrm{~b}$ & Weed \\
Pinus halepensis & 2 & Invader \\
Psidium guajava & 2 & Invader \\
Salix babylonica & 2 & Invader \\
Agave americana & 3 & Invader \\
Morus alba var. alba & 3 & Invader \\
Phytolacca dioica & 3 & Invader \\
\hline
\end{tabular}




\section{Conclusions}

Documenting information on perceptions of local communities on the contributions of alien plant species to livelihood needs in the Eastern Cape province is an important step in trying to understand and initiate a management protocol that incorporates public perceptions and values associated with alien plant species. This is also important for capturing the ecological, economic and cultural impacts associated with this category of plant species. Recording of alien plant species and analyzing patterns of floristic status, geographical distribution, biological attributes and utilization has proved to be a useful approach in understanding exotic species diversity in various areas of the world. Therefore, an understanding of the utilized species, their identities, different use categories, indigenous knowledge associated with such species and distributional changes of such useful alien plant species in the Eastern Cape province is important for making informed decisions in managing existing alien plant introductions and predicting future invasions. The value of alien plant species to local people in the Eastern Cape province is linked to their utility, therefore, a better understanding of these attributes is also important for the development of appropriate exotic plant species management plans. However, current data on the floristic status, geographical distribution, utilization and biological attributes of alien plant species in the Eastern Cape province is far from sufficient to inform management protocols of alien species. It is here recommended that additional attention be paid to evaluating the biological, ecological, economic, social and cultural impacts associated with alien plant species in the Eastern Cape province and other provinces in the Republic of South Africa.

Author Contributions: A.M. and L.J.R. conceived the research and methodology used, while Z.A. collected data and wrote the first draft. A.M. funded the research, reviewed and edited the first draft.

Funding: The authors would like to express their gratitude to the National Research Foundation (NRF), South Africa and Govan Mbeki Research and Development Centre (GMRDC), University of Fort Hare for financial support to conduct this study.

Conflicts of Interest: The authors declare no conflict of interest.

\section{References}

1. Pyšek, P.; Richardson, D.M.; Rejmanek, M.; Webster, G.L.; Williamson, M.; Kirschner, J. Alien plants in checklists and flora: Towards better communication between taxonomists and ecologists. Taxon 2004, 53, 131-143. [CrossRef]

2. UNEP (United Nations Environmental Programme). Alien Species that Threaten Ecosystems, Habitats or Species; UNEP: The Hague, The Netherlands, 2002.

3. Pyšek, P.; Richardson, D.M. Traits associated with invasiveness in alien plants: Where do we stand? In Biological Invasions, Ecological Studies 193; Nentwig, W., Ed.; Springer: Berlin, Germany, 2007; pp. 97-125.

4. Van Kleunen, M.; Weber, E.; Fischer, M. A meta-analysis of traits difference between invasive and non-invasive plant species. Ecol. Lett. 2010, 2, 235-245. [CrossRef] [PubMed]

5. Shackleton, S.E.; Shackleton, R.T. Local knowledge regarding ecosystem services and disservices from invasive alien plants in the arid Kalahari, South Africa. J. Arid Environ. 2018, 159, 22-33. [CrossRef]

6. Vilà, M.; Basnou, C.; Pyšek, P.; Josefsson, M.; Genovesi, P.; Gollasch, S.; Nentwig, W.; Olenin, S.; Roques, A.; Roy, D.; et al. How well do we understand the impacts of alien species on ecosystem services? A pan-European, cross-taxa assessment. Front. Ecol. Environ. 2010, 8, 135-144. [CrossRef]

7. Vilà, M.; Espinar, J.L.; Hejda, M.; Hulme, P.E.; Jarošík, V.; Maron, J.L.; Pergl, J.; Schaffner, U.; Sun, Y.; Pyšek, P. Ecological impacts of invasive alien plants: A meta-analysis of their effects on species, communities and ecosystems. Ecol. Lett. 2011, 14, 702-708. [CrossRef] [PubMed]

8. Pyšek, P.; Jarošík, V.; Hulme, P.E.; Pergl, J.; Hejda, M.; Schaffner, U.; Vilà, M. A global assessment of invasive plant impacts on resident species, communities and ecosystems: The interaction of impact measures, invading species' traits and environment. Glob. Chang. Biol. 2012, 18, 1725-1737. [CrossRef]

9. Foxcroft, L.C.; Pysěk, P.; Richardson, D.M.; Genovesi, P.; MacFadyen, S. Plant invasion science in protected areas: Progress and priorities. Biol. Invasions 2017, 19, 1353-1378. [CrossRef] 
10. Guerin, G.R.; Martín-Forés, I.; Sparrow, B.; Lowe, A.J. The biodiversity impacts of non-native species should not be extrapolated from biased single-species studies. Biodivers. Conserv. 2017, 27, 785-790. [CrossRef]

11. Fried, G.; Carboni, M.; Mahaut, L.; Violle, C. Functional traits modulate plant community responses to alien plant invasion. Perspect. Plant Ecol. Evol. Syst. 2019, 37, 53-63. [CrossRef]

12. Shackleton, C.M.; McGarry, D.; Fourie, S.; Gambiza, J.; Shackleton, S.E.; Fabricius, C. Assessing the effects of invasive alien species on rural livelihoods: Case examples and framework from South Africa. Hum. Ecol. 2007, 35, 113-127. [CrossRef]

13. Pfeiffer, J.M.; Voeks, R.A. Biological invasions and biocultural diversity: Linking ecological and cultural systems. Environ. Conserv. 2008, 35, 281-293. [CrossRef]

14. Novoa, A.; Kaplan, H.; Wilson, J.R.U.; Richardson, D.M. Resolving a prickly situation: Involving stakeholders in invasive cactus management in South Africa. Environ. Manag. 2016, 57, 998-1008. [CrossRef] [PubMed]

15. Kull, C.A.; Shackleton, C.M.; Cunningham, P.J.; Ducatillon, C.; Dufour-Dror, J.M.; Esler, K.J.; Friday, J.B.; Gouveia, A.C.; Griffin, A.R.; Marchante, E. Adoption, use and perception of Australian acacias around the world. Divers. Distrib. 2011, 17, 822-836. [CrossRef]

16. Jernigan, K. Plants with histories: The changing ethnobotany of Iquito speakers of the Peruvian Amazon. Econ. Bot. 2012, 66, 46-59. [CrossRef]

17. Bennett, B.C.; Prance, G.T. Introduced plants in the indigenous pharmacopoeia of Northern South America. Econ. Bot. 2000, 54, 90-102. [CrossRef]

18. Srithi, K.; Balsleu, H.; Tanming, W.; Trisonthi, C. 2017. Weed diversity and uses: A case study from tea plantations in northern Thailand. Econ. Bot. 2017, 71, 147-159. [CrossRef]

19. Baral, S.; Adhikari, A.; Khanal, R.; Malla, Y.; Kunwar, R.; Basnyat, B.; Gauli, K.; Acharya, R. Invasion of alien plant species and their impact on different ecosystems of Panchase area, Nepal. Banko Janakari 2017, 27, 31-42. [CrossRef]

20. Zengeya, T.; Ivey, P.; Woodford, D.J.; Weyl, O.; Novlona, A.; Shackleton, R.T.; Richardson, D.; Van Wilgen, B. Managing conflict generating invasive species in Souh Africa: Challenges and trade. Bothalia Afr. Biodivers. Conserv. 2017, 47. [CrossRef]

21. Levine, J.M.; D'Antonio, C.M. Forecasting biological invasions with increasing international trade. Conserv. Biol. 2003, 17, 322-326. [CrossRef]

22. Hulme, P.E.; Bacher, S.; Kenis, M.; Klotz, S.; Kühn, I.; Minchin, D.; Nentwig, W.; Olenin, S.; Panov, V.; Pergl, J.; et al. Grasping at the routes of biological invasions: A framework for integrating pathways into policy. J. Appl. Ecol. 2008, 45, 403-414. [CrossRef]

23. Bradley, B.A.; Blumenthal, D.M.; Early, R.; Grosholz, E.D.; Lawler, J.J.; Miller, L.P.; Sorte, C.J.B.; D'Antonio, C.M.; Diez, J.M.; Dukes, J.S.; et al. Global change, global trade and the next wave of plant invasions. Front. Ecol. Environ. 2011, 10, 20-28. [CrossRef]

24. Early, R.; Bradley, B.A.; Dukes, J.S.; Lawler, J.J.; Olden, J.D.; Blumenthal, D.M.; Gonzalez, P.; Grosholz, E.D.; Ibanez, I.; Miller, L.P.; et al. Global threats from invasive alien species in the twenty-first century and national response capacities. Nat. Commun. 2016, 7, 12485. [CrossRef] [PubMed]

25. Richardson, D.M.; Rejmánek, M. Trees and shrubs as invasive alien species: A global review. Divers. Distrib. 2011, 17, 788-809. [CrossRef]

26. Richardson, D.M.; Pyšek, P. Plant invasions: Merging the concept of invasiveness. ecology and community invisibility. Prog. Phys. Geogr. Earth Environ. 2006, 30, 409-431. [CrossRef]

27. Willis, A.J.; Memnott, J.; Forrester, R.I. Is there evidence for the invasive evolution of increased size among invasive plant species? Ecol. Lett. 2001, 3, 275-283. [CrossRef]

28. Stastny, M.; Schaffner, U.; Elle, E. Do vigour of introduced populations and escape from specialist herbivores contribute to invasiveness? J. Ecol. 2005, 93, 27-37. [CrossRef]

29. Vilà, M.; Weiner, J. Are invasive plant species better competitors than native plant species? Evidence from pair-wise experiments. Oikos 2004, 105, 229-238. [CrossRef]

30. Rai, R.J.; Scarborough, H.; Subedi, N.; Lamichhmane, B. Invasive plants: Do they devastate or diversify rural livelihoods? Rural farmer's perception of three invasive plants in Nepal. J. Nat. Conserv. 2012, 20, 170-176. [CrossRef]

31. Heink, U.; Kurt, J. Framing biodiversity: The case of "invasive alien species". In Concepts and Values in Biodiversity; Lanzerath, D., Friele, M., Eds.; Routledge: London, UK, 2014; pp. 73-98. 
32. Dold, A.P.; Cocks, M. The medicinal use of some weeds, problem and alien plants in the Grahamstown and Peddie districts of the Eastern Cape, South Africa. S. Afr. J Sci. 2000, 96, 467-473.

33. Semenya, S.S.; Potgieter, M.J.; Tshisikhawe, M.P.; Shava, S.; Maroyi, A. Medicinal utilization of exotic plants by Bapedi traditional healers to treat human ailments in Limpopo Province, South Africa. J. Ethnopharmacol. 2012, 144, 646-655. [CrossRef] [PubMed]

34. Shackleton, R.T.; Van Wilgen, D.R. Use of non-timber forest product from alien invasive Prosopis species (mesquite) and native trees in South Africa: Implications for management. For. Ecosyst. 2015, 2, 16. [CrossRef]

35. Maema, L.P.; Portgiter, S.; Mahlo, M.M. Invasive alien plant species used for the treatment of various disease sin Limpopo Province, South Africa. Afr. J. Tradit. Complement. Altern. Med. 2016, 13, 223-231. [CrossRef] [PubMed]

36. Mbambala, S.G.; Tshisikawe, M.P.; Masevhe, N.A. Invasive alien plants used in the treatment of HIV/AIDS-related symptoms by traditional healers of Vhembe Municipality, Limpopo province, South Africa. Afr. J. Tradit. Complement. Altern. Med. 2017, 14, 80-88. [CrossRef]

37. Semenya, S.S.; Maroyi, A. Exotics plants used therapeutically by Bapedi traditional healers for respiratory infections and related symptoms in the Limpopo province, South Africa. Indian J. Tradit. Knowl. 2018, 17, 663-671.

38. Maema, L.P.; Potgieter, M.J.; Samie, A. Ethnobotanical survey of invasive alien plant species used in the treatment of sexually transmitted infections in Waterberg district, South Africa. S. Afr. J. Bot. 2019, 121. [CrossRef]

39. Van Wilgen, B.W.; Wannenburgh, A. Co-facilitating invasive species control, water conservation and poverty relief: Achievements and challenges in South Africa's working for water programme. Curr. Opin. Environ. Sustain. 2016, 19, 7-17. [CrossRef]

40. De Neergaard, A.; Saarnak, C.; Hill, T.; Khanyile, M.; Berzosa, A.M.; Birch-Thomsen, T. Australian wattle species in the Drakensberg region of South Africa: An invasive alien or a natural resource? Agric. Syst. 2005, 85, 216-233. [CrossRef]

41. Shackleton, S.; Kirby, D.; Gambiza, J. Invasive plants: Friends or foes? Contribution of prickly pear (Opuntia ficus-indica) to livelihoods in Makana Municipality, Eastern Cape, South Africa. Dev. S. Afr. 2011, 28, 177-193. [CrossRef]

42. Bremner, A.; Park, K. Public attitudes to the management of invasive non-native species in Scottland. Biol. Conserv. 2007, 139, 306-314. [CrossRef]

43. Bertolino, S.; Genovesi, P. Spread and attempted eradication of the grey squirrel (Sciurus carolinensis) in Italy, and consequences for the red squirrel (Sciurus vulgaris) in Eurasia. Biol. Conserv. 2003, 109, 351-358. [CrossRef]

44. Lindemann-Matthies, P. Beasts or beauties? Laypersons' perception of invasive alien plant species in Switzerland and attitudes towards their management. NeoBiota 2016, 29, 15-33. [CrossRef]

45. Fischer, A.; Young, J.C. Understanding mental constructs of biodiversity: Implications for biodiversity management and conservation. Biol. Conserv. 2007, 136, 271-282. [CrossRef]

46. Fischer, A.; Van der Wal, R. Invasive plant suppresses charismatic seabird: The construction of attitudes towards biodiversity management options. Biol. Conserv. 2006, 135, 256-267. [CrossRef]

47. Genovesi, P. Limits and potentialities of eradication as a tool for addressing biological invasions. In Biological Invasions; Nentwig, W., Ed.; Springer: Berlin, Germany, 2007; pp. 385-402.

48. García-Llorente, M.; Martín-López, B.; González, J.A.; Alcorlo, P.; Montes, C. Social perceptions of the impacts and benefits of invasive alien species: Implications for management. Biol. Conserv. 2008, 141, 2969-2983. [CrossRef]

49. Sharp, R.L.; Larson, L.R.; Green, G.T. Factors influencing public preferences for invasive alien species management. Biol. Conserv. 2011, 144, 2097-2104. [CrossRef]

50. Schüttler, E.; Rozzi, R.; Jax, K. Towards a societal discourse on invasive species management: A case study of public perceptions of mink and beavers in Cape Horn. J. Nat. Conserv. 2011, 19, 175-184. [CrossRef]

51. Humair, F.; Edwards, P.J.; Siegrist, M.; Kueffer, C. Understanding misunderstandings in invasion science: Why experts don't agree on common concepts and risk assessments. NeoBiota 2014, 20. [CrossRef]

52. Van Wilgen, B.W.; Richardson, D.M. Challenges and trade-offs in the management of invasive alien trees. Biol. Invasions 2014, 16, 721-734. [CrossRef] 
53. Nkambule, N.P.; Blignaut, J.N.; Vundla, T.; Morokong, T.; Mudavanhu, S. The benefits and costs of clearing invasive alien plants in northern Zululand, South Africa. Ecosyst. Serv. 2017, 27, 203-223. [CrossRef]

54. Manyevere, A.; Muchaonyerwa, P.; Laker, M.C.; Mnkeni, P.N.S. Farmers' perspectives with regard to crop production: An analysis of Nkonkobe municipality, South Africa. J. Agric. Rural Dev. Trop. Subtrop. 2014, $115,41-53$.

55. Mucina, L.; Rutherford, M.C. The Vegetation of South Africa, Lesotho and Swaziland; Strelitzia 19; South African National Biodiversity Institute: Pretoria, South Africa, 2006.

56. Chambers, R. Participatory rural appraisal (PRA): Challenges, potentials and paradigm. World Dev. 1994, 22, 1437-1454. [CrossRef]

57. Mueller, J.G.; Assanou, I.H.B.; Guimbo, I.D.; Almedom, A.M. Evaluating rapid participatory rural appraisal as an assessment of ethnoecological knowledge and local biodiversity patterns. Conserv. Biol. 2010, 24, 140-150. [CrossRef] [PubMed]

58. Maroyi, A. Exotic plants in indigenous pharmacopoeia of south-central Zimbabwe: Traditional knowledge of herbal medicines. Res. J. Bot. 2017, 12, 46-52. [CrossRef]

59. Bridson, D.; Foreman, L. The Herbarium Handbook; Kew, Royal Botanic Gardens: Richmond, BC, Canada, 1998.

60. Victor, J.E.; Koekemoer, M.; Fish, L.; Smithies, S.J.; Mössmer, M. Herbarium Essentials: The Southern African Herbarium User Manual; National Botanical Institute: Pretoria, South Africa, 2004.

61. Carter, R.; Bryson, C.T.; Darbyshire, S.J. Preparation and use of voucher specimens for documenting research in weed science. Weed Technol. 2007, 21, 1101-1108. [CrossRef]

62. Crouch, M.; McKenzie, H. The logic of small samples in interview-based qualitative research. Soc. Sci. Inf. 2006, 45, 483-499. [CrossRef]

63. Guest, G.; Bunce, A.; Johnson, L. How many interviews are enough? an experiment with data saturation and variability. Field Methods 2006, 18, 59-82. [CrossRef]

64. Latham, J.R. A framework for leading the transformation to performance excellence part I: CEO perspectives on forces, facilitators, and strategic leadership systems. Qual. Manag. J. 2013, 20, 12-33. [CrossRef]

65. Shuaib, M.; Ahmed, S.; Ali, K.; Ilyas, M.; Hussain, F.; Urooj, Z.; Shah, S.S.; Kumar, T.; Shah, M.; Khan, I.; et al. Ethnobotanical and ecological assessment of plant resources at District Dir, Tehsil Timergara, Khyber Pakhtunkhwa, Pakistan. Acta Ecol. Sin. 2019, 39, 109-115. [CrossRef]

66. Umair, M.; Altaf, M.; Abbasi, A.M. An ethnobotanical survey of indigenous medicinal plants in Hafizabad district, Punjab-Pakistan. PLoS ONE 2017, 12, e0177912. [CrossRef] [PubMed]

67. Kankara, S.S.; Ibrahim, M.H.; Mustafa, M.; Go, R. Ethnobotanical survey of medicinal plants used for traditional martenal healthcare in Kalsina state, Nigeria. S. Afr. J. Bot. 2015, 97, 165-175. [CrossRef]

68. Hussain, W.; Ullar, M.; Dartagir, G.; Badshah, L. Quantitative ethnobotanical appraisal of medicinal plants used by inhabitants of lower Kurram, Kuraam agency, Pakistan. Avicenna J. Phytomed. 2018, 8, 313-329. [PubMed]

69. Ahmad, K.S.; Hamid, A.; Nawaz, F.; Hameed, M.; Ahmad, F.; Deng, J.; Akhtar, N.; Wazarat, A.; Mahroof, S. Ethnopharmacological studies of indigenous plants in Kel village, Neelum Valley, Azad Kashmir, Pakistan. J. Ethnobiol. Ethnomed. 2017, 13, 68. [CrossRef] [PubMed]

70. Hammer, Ø.; Harper, D.A.T.; Ryan, R.D. PAST: Palaeontological statistics software package for education and data analysis. Palaeontol. Electron. 2001, 4, 9.

71. South Africa. Conservation of Agricultural Resources Act No. 43 of 1983; Government Printer: Pretoria, South Africa, 1983.

72. National Department of Agriculture. CARA Legislation Made Easy: The Conservation of Agricultural Resources Act, 1983 (Act No. 43 of 1983) (CARA); Government Printer: Pretoria, South Africa, 2002.

73. Wilson, J.R.; Ivey, P.; Manyama, P.; Nänni, I. A new national unit for invasive species detection, assessment and eradication planning. S. Afr. J. Sci. 2013, 109. [CrossRef]

74. Van Wilgen, B.W.; Le Maitre, D.C.; Cowling, R.M. Ecosystem services, efficiency, sustainability and equity: South Africa's working for water programme. Trends Ecol. Evol. 1998, 13, 378. [CrossRef]

75. Hope, R.A. Water, workfare and poverty: The impact of the working for water programme on rural poverty reduction. Environ. Dev. Sustain. 2006, 8, 139-156. [CrossRef]

76. Van Wilgen, B.W.; Khan, A.; Marais, C. Changing perspectives on managing biological invasions: Insights from South Africa and the working for water programme. In Fifty Years of Invasion Ecology: The Legacy of Charles Elton; Richardson, D.M., Ed.; Wiley-Blackwell: Oxford, UK, 2011; pp. 377-393. 
77. McConnachie, M.M.; Cowling, R.M.; Van Wilgen, B.W.; McConnachie, D.A. Evaluating the cost-effectiveness of invasive alien plant clearing: A case study from South Africa. Biol. Conserv. 2012, 155, 128-135. [CrossRef]

78. Maroyi, A.; Van der Maesen, L.J.G. Gloriosa superba L. (Colchicaceae): Ethnobotany and economic importance. Scr. Bot. Belg. 2013, 50, 408-416.

79. Nel, J.L.; Richardson, D.M.; Rouget, M.; Mgidi, T.N.; Mdzeke, N.; Le Maitre, D.C.; Van Wilgen, B.W.; Schonegevel, L.; Henderson, L.; Neser, S. A proposed classification of invasive alien plant species in South Africa: Towards prioritizing species and areas for management action. S. Afr. J. Sci. 2004, 100, 53-64.

80. Alencar, N.L.; de Sousa Araujo, T.A.; de Amorim, E.L.C.; de Albuquerque, U.P. The inclusion and selection of medicinal plants in traditional pharmacopoeias-evidence in support of the diversification hypothesis. Econ. Bot. 2010, 64, 68-79. [CrossRef]

81. Alencar, N.L.; Santoro, F.R.; Albuquerque, U.P. What is the role of exotic medicinal plants in local medical systems? A study from the perspective of utilitarian redundancy. Rev. Bras. Farmacogn. 2014, 24, 506-515. [CrossRef]

(C) 2019 by the authors. Licensee MDPI, Basel, Switzerland. This article is an open access article distributed under the terms and conditions of the Creative Commons Attribution (CC BY) license (http://creativecommons.org/licenses/by/4.0/). 